\title{
Variation in Chemical Composition and Antimicrobial Activities of Essential oil of Leaves of Knob Wood, Zanthoxylum chalybeum Collected from Three Different Places of Eastern Ethiopia
}

\author{
TADESSE MOLLA TIGNEH* and NEELAIAH BABU G. \\ Department of Chemistry, College of Natural and Computational Sciences, \\ Haramaya University, Dire Dawa, Ethiopia. \\ *Correponding author E-mail: tadessemt@gmail.com \\ http://dx.doi.org/10.13005/ojc/360322
}

(Received: October 14, 2019; Accepted: June 01, 2020)

\begin{abstract}
The chemical compositions and functional properties of Zanthoxylum chalybeum (Knob wood) leave essential oils varied as growing locations. In this study, the variation in chemical composition and antimicrobial activities of the hydro distilled essential oils of the plant fresh leaves collected from three different growing places in Eastern Ethiopia (Awale, Dire Dawa Administration; Awaday, Haramaya subdistrict, and Lange, Kersa Subdistrict, East Hararghe Zone of Oromia Region), were investigated. The chemical composition of the respected essential oils, as determined by the GC-MS analysis, 13, 12 and 17 compounds representing $99.98 \%, 100.00 \%$ and $100.00 \%$ of the total leaves essential oil from the plant growing in Awale, Awaday, and Lange, respectively, were identified. The essential oils of Awale, Awaday and Lange were mostly $\beta$-phellanderene (23.96\%, 45.31\%, $23.45 \%$ respectively), whereas highest amount of other components in the essential oils of Lange: terpine-4-ol (25.02\%) and sabinene (11.73\%); Awaday. $\alpha$-phellanderene (12.85\%) and Awale: the sole $\beta$-myrcene $(29.33 \%)$ was identified. In vitro antimicrobial activity in $20 \mu \mathrm{L}$ dose of each essential oil evaluated by the disc diffusion method indicated strong antibacterial activities against the test bacteria (S.thyphi, Str. agalactia, S.aureus and E.coli) and slight antifungal activities against the test fungi (A.niger, F.oxysporium). The essential oils' major constituents, the monoterpenoids, such as phellandrenes ( $\alpha$ and $\beta$ ), terpinen-4-ol and sabinene could be responsible for the significant antimicrobial activities in this study. The plant essential oils' chemical composition and the antimicrobial activities significantly differ with growing locations. The findings confirm the plant's medicinal properties in traditional uses. The results open the many possibilities for further research on biocidal and antimicrobial activities of the essential oil and its individual components of the species growing in different regions of Ethiopia.
\end{abstract}

Keywords: Zanthoxylum chalybeum, Essential oil, $\beta$-Phellandrene, Hydrodistillation, Antimicrobia.

\section{INTRODUCTION}

Natural products albeit their chemical composition unknown are utilized by humankind for thousands of years as sources of various human needs such as medicines, therapeutic needs and drugs $^{1}$. Written documents about the knowledge of traditional uses of plants hardly exist ${ }^{2}$ thus obscuring

This is an Open Access article licensed under a Creative Commons license: Attribution 4.0 International (CC- BY). Published by Oriental Scientific Publishing Company @ 2018 
the discovery of new drug sources, their sustainable uses 3 and the retention of their actual values by the respective countries of origins. No adequate quantitative data that could be used to assess the indigenous knowledge on the use and management of medicinal plants in Eastern Ethiopia exists ${ }^{4}$. Documenting traditional medicines and remedies is paramount in order to promote their safety, effectiveness, and affordability ${ }^{3}$.

In Africa, up to $80 \%$ of the population uses traditional medicine for primary health care. $25 \%$ of modern medicines are made from plants first used traditionally ${ }^{5}$. About $40 \%$ of all pharmaceutical presently in use are derived from natural sources (plants, fungi, and other microorganisms, animals, etc.), either used directly or with some modifications ${ }^{6}$. For example, in China, the plant Artemisia annua is used to treat resistant malaria; in South Africa, the plant Sutherlandia microphylla is used to increase vitality in HIV/AIDS patients ${ }^{3}$.

Traditional medicines are affordable at a time of soaring health-care costs and nearly universal austerity and help us to cop the relentless rise of chronic non-communicable diseases. The interest in traditional medicine and complementary medicine is growing continuously around the world 7 . In Ethiopia, $80 \%$ of the human population and $90 \%$ of livestock rely on traditional medicine ${ }^{8}$. The widespread use of traditional medicine among the population in Ethiopia could be attributed to cultural acceptability, its attributed efficacy against certain types of diseases, physical accessibility, and economic affordability as compared to modern medicine. Natural products are environmentally friendly alternatives to recurring pathogen-resistant drugs and environmentally hazardous chemicals ${ }^{9}$. New alternative antibacterial agents for mouth rinses are necessitated as some synthetic mouth rinses suffer, like chlorhexidine, from staining teeth ${ }^{10}$ and, like triclosan, from environmentally unfriendly; likewise, chloramphenicol, an effective broadspectrum antibacterial drug, suffers from being a hemotoxic drug ${ }^{11}$. Traditional medicinal natural products are available and better biodegradable as compared to synthetic agents. ${ }^{12}$

The current research on the Zanthoxylum chalybeum species locally known as gadda [in Oromgna language] which is used traditionally to treat mainly Gofla (swollen body part) in humans and life stocks, is a new kind in Eastern Ethiopia. Gofla is a cancerous disease of chronic origin of infectious (bacterial, viral, fungal, protozoa, parasitic, etc.) and non-infectious diseases. Gofla could be transmitted from mother to child, vector to animals/ human, animals/insects to human; injury incurred to the body part. The plant is also used to treat aphrodisiac problems and the various child ailments (e.g. stomach problems, fever, diarrhea, etc.); as analgesics and antipyretics; in a nutshell as food and medicinal plant. The plant is used to clean respiratory tract airways obstruction, to treat psychiatric, fainting and dizziness problems, to enhance women's fertility, to ease childbirth processes and to maintain oral hygiene. Plant parts (root/root bark/stem bark/leaves/ flowers/seeds) are prepared alone or mixed with other substances (e.g. mixed with food, honey, tea, coffee pericarps, other plants, etc.) in the powder, paste, decoction, juice, and infusion, macerated or smoke form for use. Administration of the plant could be orally (chewing, eating or drinking as tonic drinks), nasally, topically or taking bath with its juices, infusion or aqueous extracts.

In animals, the plant is used to treat various animal ailments including body inflammation, anthrax, diarrhea, Exo and endo parasites, swollen neck, urinary blockage, and mastitis. It is used to enhance reproductive fertility in animals, milk production in cows and honey production in bees. It is used as charcoal and to disinfect milk gourds.

What motivated this research on the plant's leaves was that the Zanthoxylum chalybeum plant parts are being sold in the open market places of Eastern Ethiopia by Market vendors as an important traditional medicinal plant mainly for the treatment of cancerous diseases locally known as Gofla; aphrodisiac problems, severe colds, pneumonia, toothache, etc. The researcher preferred to carry out the research on the leaves of the plant to the roots and stems for the leaves are available throughout the year and to avoid the uprooting of the plant in the course of collecting samples for the research. Since the chemical composition of a given species varies due to intrinsic and extrinsic factors with time, such variations need documentation for the forthcoming various researches and subsequent studies on the medicinally important plants as Zanthoxylum chalybeum species. Therefore, the present study was 
conducted to identify the chemical composition and the antibacterial potentiality of the plant leaf essential oil.

\section{EXPERIMENTAL}

\section{MATERIALS AND METHODS}

\section{Collection of the plant material}

The plant Zanthoxylum chalybeum was collected in February 2017 from three different places of Eastern Ethiopia namely Awale, Dire Dawa Administration $\left(9.50^{\circ} \mathrm{N}, 42.05^{\circ} \mathrm{E} ; 1979 \mathrm{mtr}\right)$; Awaday, Haramaya Sub-district $\left(9.35^{\circ} \mathrm{N}, 42.03^{\circ} \mathrm{E} ; 2009 \mathrm{mtr}\right)$, Lange, Kersa Sub-district (9.44N, 41.79 $\mathrm{E}$; $2060 \mathrm{mtr})$ in East Hararghe Zone, Oromia Region. Awale located in Dire Dawa administrative zone which is an arid region of Ethiopia. The weather is hot for the most of the year. Both Awaday (Haramaya Sub-district, Oromia region) and Lange (Kersa District, Oromia region) located at the edge of plateau. These both locations are cooler as they are located more than 1850 meters from main sea level. Botanical specimens of the plant were identified and deposited at the Herbarium of the School of Plant Science, Haramaya University, Haramaya, Ethiopia. The collected plant was stored at room temperature until further study. ${ }^{13}$

\section{Methods}

\section{Preparation of extracts}

The fresh leaves of Zanthoxylum chalybeum $(200 \mathrm{~g})$ of each sample were packed in an air tight polyethylene bag and were stored in the refrigerator at $4^{\circ} \mathrm{C}$.

The essential oil of the fresh leave $(200 \mathrm{~g}$ of the leaf mixed with $1200 \mathrm{~mL}$ distilled water) was extracted by hydro distillation using Clevenger's apparatus at atmospheric pressure for a period of six hours until complete exhaustion ${ }^{14}$. The oil was then separated from the aqueous layer with $10 \mathrm{~mL}$ of chloroform using a separatory funnel. The chloroform oil mixture was dried with $5 \mathrm{~g}$ of anhydrous sodium sulphate $\left(\mathrm{Na}_{2} \mathrm{SO}_{4}\right)$ and filtered using Whattman No 1 filter paper and was concentrated by using a rotary evaporator. The oil obtained was stored in a sealed amber-colored vial at $4^{\circ} \mathrm{C}$ in the refrigerator for GC-MS analysis and antimicrobial tests.

\section{Spectrometric analysis of Zanthoxylum chalybeum leaves essential oils}

The essential oil of Zanthoxylum chalybeum analysis was done using the GC-MS system, an Agilent Technology Model 7820A fitted with HP-5 MS column (30 m x $0.250 \mathrm{~mm}$ internal diameter coated with $5 \%$ phenyl and $95 \%$ methylpolysiloxane film thickness $0.25 \mu \mathrm{m}$, stationary phase. The column temperature was programmed from 50 to $120^{\circ} \mathrm{C}$ at $20^{\circ} \mathrm{C} / \mathrm{min}, 120$ to $150^{\circ} \mathrm{C}$ at $4^{\circ} \mathrm{C} / \mathrm{min}, 150$ to $250^{\circ} \mathrm{C}$ at $20^{\circ} \mathrm{C} / \mathrm{min}$ (with $10 \mathrm{~min}$ hold time) and $3.5 \mathrm{~min}$ solvent delay. The injector and the detector (5977E MSD) temperatures were maintained at $325^{\circ} \mathrm{C}$ and $350^{\circ} \mathrm{C}$ respectively. Helium was used as a carrier gas at a flow rate of $1 \mathrm{~mL} / \mathrm{min}$. The interface temperature was $280^{\circ} \mathrm{C}$. The mass spectrometer was operated at an electron impact of $70 \mathrm{ev}$ with an ion source temperature of $230^{\circ} \mathrm{C}$. The constituents of the essential oil were identified by their retention time $\mathrm{MH}$ (Mass Hunter) Library search NIST (National Institute of Standard and Technology) 14 Library and by comparison with mass spectra data available in the literature. The percentage of each constituent in the oil was determined based on GC peak areas.

\section{Test for antibacterial activity Inoculum preparation}

The test bacteria strains Staphylococcus aureus, Streptococci agalectia, Escherichia coli and Salmonella typhimurium from the stock cultures were streak on Muller Hinton plates and incubated for 24 hours. The bacteria colonies well separated were used as inoculums. The inoculums were transferred with a bacteriological loop to autoclaved Mueller Hinton molten agar cooled to $45^{\circ} \mathrm{C}$ in a water bath. The contents were mixed by swirling the flasks gently. The medium was then poured to sterile Petri plates, allowed to solidify and used for bio-test ${ }^{15}$. For the fungi test, mycelial plug from stock culture was transferred to PDA plates and incubated for 5 to 7 days. Then a spore of fungi was harvested with washing the surface of the colony using $10 \mathrm{~mL}$ sterile distilled water and was transferred to $250 \mathrm{~mL}$ autoclaved PDA cooled to about $45^{\circ} \mathrm{C}$ in a water bath. The medium containing spore or mycelia suspension was poured to sterile plates, allowed solidify and was used for the disk diffusion bioassay ${ }^{15}$.

\section{Antibacterial and Antifungal activity screening}

The essential oil extracts of Zanthoxylum chalybeum leaves from the hydrodistillation were evaluated In vitro for antimicrobial activity by using the paper disc diffusion method against two positive bacteria (Staphylococcus aureus and Streptococcus agalectiae), two Gram-negative 
bacterium (Escherichia coli and Salmonella typhimurium) and two fungi (Aspergillus niger and Fusarium oxysporum). The bacterium cultures were inoculated into the Muller Hinton Agar (MHA) and incubated at $37^{\circ} \mathrm{C}$. Fungal cultures were inoculated into Potato Dextrose Agar (PDA) and incubated at $27^{\circ} \mathrm{C}$. The bacteria were obtained from the Ethiopia Public Health Institute, Addis Ababa. The fungi (Aspergillus niger from infected groundnut, and Fusarium oxysporum from infected maize) were obtained in Plant Science Laboratory, Haramaya University, respectively. Chloramphenicol was used as a standard drug against bacteria whereas Tilt was used against fungi. Approximately, $10 \mathrm{~mL}$ of sterile MHA (for bacteria) and PDA (for fungi) were poured into sterile culture plates and allowed to set in. From each extract, $20 \mu \mathrm{L}$ of the oil was loaded to the discs of $6 \mathrm{~mm}$ in diameter in three replications. The impregnated paper discs were loaded on the plates. The plates were incubated at $37^{\circ} \mathrm{C}$ (for bacteria) and $27^{\circ} \mathrm{C}$ (for fungi) 24 hours. The diameter of the zone of inhibition 9 for each bacteria triplicates and fungus triplicates was measured horizontally and vertically after the incubation period. The net diameter of the zone of inhibition for each oil per each microorganism was recorded. The average measurements were recorded for bioassay analysis. The antifungal and antibacterial activity of the plant extracts were evaluated using the measurement results against the test organisms ${ }^{15}$.

\section{RESULTS AND DISCUSSION}

\section{Variation in essential oil chemical composition}

The components of the Zanthoxylum chalybeum leaves essential oils with their respective percentage composition, molecular formula and retention time as analyzed by GC-MS from three different places namely Awale, Awaday and Lange of Eastern Ethiopia are presented in Table 1, 2 and 3 with their respective chromatograms (Fig. 1, 2 and 3). Thirteen, twelve, and seventeen major components were identified in various proportions from Awale, Awaday, and Lange, respectively accounting for each $100 \%$ of the oil composition. The Awale, Awaday, and Lange $(99.98 \%, 100 \%$, and $100 \%)$ essential oils constituents are terpenes, $90 \%$ of each essential oil constituents are monoterpenes, typical of essential oil composition. Sesquiterpenes, diterpenes, hydrocarbons (and their derivatives) constitute the rest.
The total constituents of the essential oils' terpenoids accounted for Awale (98.46\%), Awaday (90.44\%) and Lange (83.00\%) in differing proportions. Hydrocarbons and their derivatives accounted for Lange (17.00\%) and Awaday (9.56\%) far exceeded that of Awale (1.52\%) showing a contrasting composition variation between them.

The Awale essential oil (Table 1) constitutes $88.28 \%$ monoterpenoids, $9.71 \%$ of themare oxygenated monoterpenes. The monoterpenoids $\beta$-myrcene $(29.33 \%), \beta$-phellandrene $(23.96 \%)$, terpinen-4-ol $(9.71 \%)$, sabinene (9.31\%), $\alpha$-phellandrene $(7.33 \%)$, $\alpha$-pinene $(2.59 \%), \beta$-ocimene $(2.31 \%), \Upsilon$-terpinene $(2.26 \%)$ and $\alpha$-terpinene (1.48\%); the sesquiterpene hydrocarbon, $\beta$-copaen (2.29\%); the monocyclic diterpene hydrocarbon camphorene isomers $(7.49 \%)$ as m-camphorene $(4.86 \%)$, p-camphorene (3.03\%); hydrocarbon derivatives as 3, 3-dimethyl-4(methylamino)-2-Butanone (1.52\%) were identified by the GC-MS analysis. Thus, thirteen components constituting $99.98 \%$ of the Awale essential oil composition were identified by the GC-MS analysis.

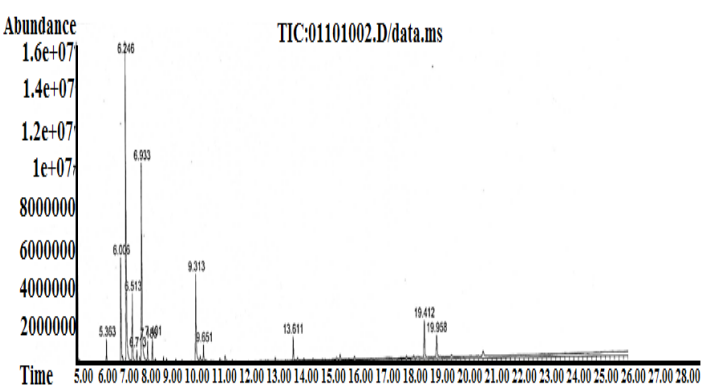

Fig. 1. Chromatogram for essential oil of Z. chalybeum leaves, Awale, Dire Dawa

Table 1: Zanthoxylum chalybeum leaves essential oil chemical composition, Awale

\begin{tabular}{ccccc}
\hline Peak\# & RT & MF & EO Components & \%Concentration \\
\hline 1 & 5.363 & $\mathrm{C}_{10} \mathrm{H}_{16}$ & $\alpha$-Pinene & 2.59 \\
2 & 6.006 & $\mathrm{C}_{10} \mathrm{H}_{16}$ & Sabinene & 9.31 \\
3 & 6.246 & $\mathrm{C}_{10} \mathrm{H}_{16}$ & $\beta$-Myrcene & 29.33 \\
4 & 6.513 & $\mathrm{C}_{10} \mathrm{H}_{16}$ & $\alpha$-Phellandrene & 7.33 \\
5 & 6.713 & $\mathrm{C}_{10} \mathrm{H}_{16}$ & $\alpha$-Terpinene & 1.48 \\
6 & 6.933 & $\mathrm{C}_{10} \mathrm{H}_{16}$ & $\beta$-Phellandrene & 23.96 \\
7 & 7.188 & $\mathrm{C}_{10} \mathrm{H}_{16}$ & $\beta$-Ocimene & 2.31 \\
8 & 7.401 & $\mathrm{C}_{10} \mathrm{H}_{16}$ & -Terpinene & 2.26 \\
9 & 9.313 & $\mathrm{C}_{10} \mathrm{H}_{18} \mathrm{O}$ & Terpinen-4-ola & 9.71 \\
10 & 9.651 & $\mathrm{C}_{7} \mathrm{H}_{15} \mathrm{NO}$ & 3,3-dimethyl-4- & \\
& & & (methylamino)-2 & \\
& & & -Butanoned 1.52 & \\
11 & 13.611 & $\mathrm{C}_{15} \mathrm{H}_{24}$ & $\beta$-Copaenb & 2.29 \\
12 & 19.412 & $\mathrm{C}_{20} \mathrm{H}_{22}$ & m-Camphorenec & 4.86 \\
13 & 19.958 & $\mathrm{C}_{20} \mathrm{H}_{22}$ & p-Camphorenec & 3.03 \\
\hline
\end{tabular}

'a', 'b' ,'c' ,'d' represents as they are designate 
The Awaday plant species leaves essential oil (Table 2) constituted $88.53 \%$ monoterpenoids of which $12.89 \%$ are oxygenated monoterpenes. In the area, the monoterpenoids $\beta$-phellandrene $(45.31 \%)$, terpinen-4-ol (12.89\%), $\alpha$-phellandrene (12.85\%), sabinene $(6.36 \%)$, $\Upsilon$-terpinene (3.16\%), $\beta$-ocimene (2.68\%), $\alpha$-pinene (3.64\%) and $\alpha$-terpinene (1.63\%) were identified. Hydrocarbons and their derivatives amounting to $9.56 \%$ were identified as cyclodecane (1.95\%), 1-octanol (2.06\%) and decanal (5.55\%). $100.0 \%$ of the Awaday essential oil composition was identified using GC-MS analysis.

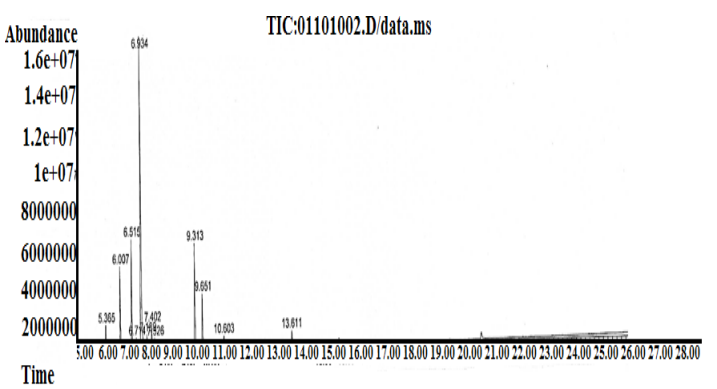

Fig. 2. Chromatogram for essential oil of Z.chalybeum leaves, Awaday, Haramaya

Table 2: Zanthoxylum chalybeum essential oil chemical composition, Awaday

\begin{tabular}{ccccc}
\hline Peak\# & $\mathrm{RT}$ & $\mathrm{MF}$ & Components & \%Concentration \\
\hline 1 & 5.365 & $\mathrm{C}_{10} \mathrm{H}_{16}$ & $\alpha$-Pinene & 3.64 \\
2 & 6.007 & $\mathrm{C}_{10} \mathrm{H}_{16}$ & Sabinene & 6.36 \\
3 & 6.515 & $\mathrm{C}_{10} \mathrm{H}_{16}$ & $\alpha$-Phellandrene & 12.85 \\
4 & 6.513 & $\mathrm{C}_{10} \mathrm{H}_{16}$ & $\alpha$-Terpinene & 1.63 \\
5 & 6.934 & $\mathrm{C}_{10} \mathrm{H}_{16}$ & $\beta$-Phellandrene & 45.31 \\
6 & 7.189 & $\mathrm{C}_{10} \mathrm{H}_{16}$ & $\beta$-Ocimene & 2.69 \\
7 & 7.402 & $\mathrm{C}_{10} \mathrm{H}_{16}$ & r-Terpinene & 3.16 \\
8 & 7.526 & $\mathrm{C}_{8} \mathrm{H}_{18} \mathrm{O}$ & 1-octanolc & 2.06 \\
9 & 9.313 & $\mathrm{C}_{10} \mathrm{H}_{18} \mathrm{O}$ & Terpinen-4-ola & 12.89 \\
10 & 9.651 & $\mathrm{C}_{10} \mathrm{H}_{20} \mathrm{O}$ & Decanalc & 5.55 \\
11 & 10.603 & $\mathrm{C}_{10} \mathrm{H}_{16}$ & Cyclodecanec & 1.95 \\
12 & 13.611 & $\mathrm{C}_{15} \mathrm{H}_{24}$ & $\beta$-Copaenb & 1.91 \\
\hline
\end{tabular}

'a', 'b' ,'c', 'd' represents as they are designated

The Lange Zanthoxylum chalybeum plant species leaves essential oil (Table 3) constitutes $83 \%$ monoterpenoids, $25 \%$ of them were oxygenated monoterpenes. The major monoterpenoids: 4-terpineol (25.02\%), $\beta$-phellandrene $(23.45 \%)$, sabinene $(11.73 \%), \alpha$-phellandrene $(6.42 \%)$, $\Upsilon$-terpinene (5.42\%), $\beta$-ocimene (5.11\%), $\alpha$-terpinene $(2.5 \%), \alpha$-pinene $(2.39 \%)$, and the minor z-ocimene $(0.99 \%)$; the hydrocarbons (and their derivatives) amounting $17 \%$ as phosphinic amide (2.82\%), phenylephrine (2.58\%), ethylamine, 2-(adamatan-1- yl)-1-methyl- (1.39\%), 1-(3,5-dimethyl-1adamatanoyl) semicarbazide $(1.67 \%)$, benzeneethanamine, 4-methoxy (1.07\%), m-methoxyamphetamine (4.98\%) were identified. $100.0 \%$ of the Lange essential oil composition was identified using GC-MS analysis.

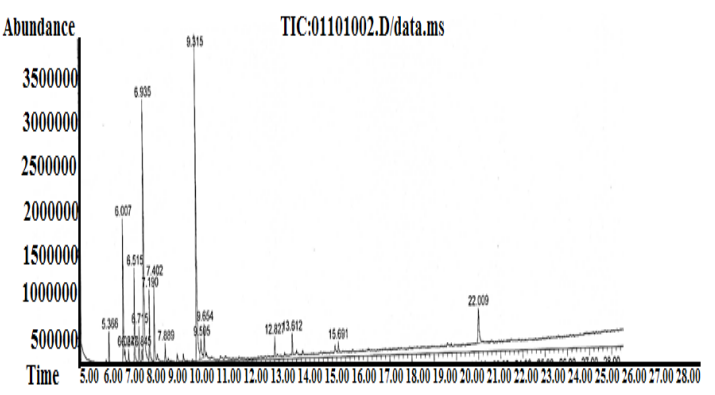

Fig. 3. Chromatogram for essential oil of Z. chalybeum Leaves, Lange, Kersa

Table 3: Zanthoxylum chalybeum leaves essential oil chemical composition, Lange

\begin{tabular}{|c|c|c|c|c|}
\hline Peak\# & \# $\quad \mathrm{RT}$ & MF & Component & ncentration \\
\hline 1 & 5.366 & $\mathrm{C}_{10} \mathrm{H}_{16}$ & $\alpha$-Pinene & 2.39 \\
\hline 2 & 6.007 & $\mathrm{C}_{10} \mathrm{H}_{16}$ & Sabinene & 9.87 \\
\hline 3 & 6.082 & $\mathrm{C}_{10} \mathrm{H}_{16}$ & Sabinene & 1.86 \\
\hline 4 & 6.247 & $\mathrm{C}_{2} \mathrm{H}_{4} \mathrm{CINO}$ & Chloroacetamide b & 1.27 \\
\hline 5 & 6.515 & $\mathrm{C}_{10} \mathrm{H}_{16}$ & $\alpha$-Phellandrene & 6.42 \\
\hline 6 & 6.715 & $\mathrm{C}_{10} \mathrm{H}_{16}$ & $\alpha$-Terpinene & 2.50 \\
\hline 7 & 6.845 & $\mathrm{C}_{10} \mathrm{H}_{16}$ & z- Ocimene & 0.99 \\
\hline 8 & 6.935 & $\mathrm{C}_{10} \mathrm{H}_{16}$ & $\beta$-Phellandrene & 23.45 \\
\hline 9 & 7.190 & $\mathrm{C}_{10} \mathrm{H}_{16}$ & $\beta$-Ocimene & 5.11 \\
\hline 10 & 7.402 & $\mathrm{C}_{10} \mathrm{H}_{16}$ & $\Upsilon$-Terpinene & 5.42 \\
\hline 11 & 7.889 & $\mathrm{C}_{2} \mathrm{H}_{4} \mathrm{CINO}$ & Chloroacetamide b & 1.22 \\
\hline 12 & 9.315 & $\mathrm{C}_{10} \mathrm{H}_{18} \mathrm{O}$ & 4-Terpineola & 25.02 \\
\hline 13 & 9.505 & $\mathrm{C}_{2} \mathrm{H}_{12} \mathrm{NOP}$ & Phosphinic amide b & 2.82 \\
\hline 14 & 9.654 & $\mathrm{C}_{9} \mathrm{H}_{13} \mathrm{NO}_{2}$ & Phenylephrine b & 2.58 \\
\hline 151 & 12.827 & $\mathrm{C}_{13} \mathrm{H}_{23} \mathrm{~N}$ & $\begin{array}{c}\text { Ethylamine, } \\
\text { 2-(adamatan-1-yl) } \\
\text {-1-methyl- }{ }^{-}\end{array}$ & 1.39 \\
\hline 161 & 13.612 & $\mathrm{C}_{14} \mathrm{H}_{23} \mathrm{~N}_{3} \mathrm{O}_{2}$ & $\begin{array}{l}\text { 1-(3,5-Dimethyl-1- } \\
\text { adamatanoyl) } \\
\text { semicarbazide }^{b}\end{array}$ & 1.67 \\
\hline 171 & 15.691 & $\mathrm{C}_{10} \mathrm{H}_{15} \mathrm{NO}$ & $\begin{array}{c}\text { Benzeneethanamine, } \\
\text { 4-methoxy- }{ }^{\mathrm{b}}\end{array}$ & 1.07 \\
\hline 18 & 22.09 & $\mathrm{C}_{10} \mathrm{H}_{15} \mathrm{NO}$ & m-Methoxyamphetamine ${ }^{b}$ & 4.98 \\
\hline
\end{tabular}

Peak \# 4 and 11 are counted as one for they are the same compounds with different RT values. 'a', 'b' represents as they are designated

\section{Chemical composition comparison of the samples from the three places}

The chemical composition of the plants collected from Awale, Awaday, and Lange (Table 4) shown insignificant variations with a total composition of monoterpenoid components. Monoterpenoids are the most dominant components in the three places 
with almost in the same proportions. But they differ in the composition of individual components. The common monoterpenes percentage of abundance in the order of Awale, Awaday, Lange are $\alpha$-pinene (2.59\%, 3.64\%, 2.39\%), $\alpha$-phellandrene $(7.33 \%$, $12.85 \%, 6.42 \%)$, and $\beta$-phellandrene $(23.96 \%$, 45.31\%, 23.45\%); they are more abundant in Awaday essential oil than Awale and Lange essential oils; sabinene $(9.31 \%, 6.36 \%, 11.73 \%)$, $\alpha$-terpinene (1.48\%, 1.63\%, 2.50\%), $\beta$-ocimene $(2.32 \%, 2.69 \%$, $5.11 \%)$, -terpinene $(2.26 \%, 3.16 \%, 5.42 \%)$ and terpinen-4-ol (9.71\%, 12.89\%, 25.02\%) are more abundant in Lange than Awale and Awaday essential oils. Solely, $\beta$-myrcene $(29.33 \%$ ) appeared in Awale and z-ocimene (0.99\%) in Lange area. Sesquiterpene hydrocarbon, $\beta$-Copaen, appeared in Awale (2.29\%) and Awaday (1.91\%) areas. Monocyclic diterpene hydrocarbons, camphorene (7.89\%), solely appeared in Awale as m-camphorene (4.86\%) and p-camphorene (3.03\%). Hydrocarbons and their derivatives appeared: Awale (1.52\%) as 3,3-dimethyl-4-(methylamino)-2-Butanone (1.52\%); Awaday (9.56\%) as cyclodecane (1.95\%), decanal (5.55\%) and 1-octanol (2.06\%); Lange (17.00\%) as Ethylamine, 2-(adamatan-1-yl)-1-methyl-(1.39\%), 1-(3,5-Dimethyl-1-adamatanoyl) semicarbazide (1.67\%) and m-methoxyamphetamine (4.98\%) were identified. Thus, the variations confirm the chemical composition of the essential oils from the three places varies as their sources.

The average percentage compositions of the major four common compounds of the respected places are tabulated in Table 5 as shown below.

Referring to Table 5 above, the most abundant terpene of the species in Eastern Ethiopia is $\beta$-phellandrene $(30.91 \%)$, followed by terpinen4-ol (15.87\%), sabinene (9.13\%), $\alpha$-phellandrene (8.87\%). $\beta$-phellandrene and $\alpha$-phellandrene are more plentiful in Awaday than Awale and Lange; terpinen-4-ol and sabinene are more plentiful in Lange than Awale and Awaday. The Eastern Ethiopia Zanthoxylum chalybeum is mainly characterized by phellandrene ( $\alpha$ and $\beta$ isomers) on average $40 \%$ abundance with $\beta$-phellandrene as the main component followed by terpinen-4-ol with $16 \%$ and sabinene with $9 \%$ average abundance.
Table 4: Zanthoxylum chalybeum leaves essential oils chemical composition variation

\begin{tabular}{|c|c|c|c|}
\hline Identified Compounds & Awale(\%) & Awaday(\%) & Lange(\%) \\
\hline Monoterpines & - & - & - \\
\hline$\alpha$-Pinene & $2.59^{b}$ & $3.64^{a}$ & $2.39^{c}$ \\
\hline Sabinene & $9.31^{b}$ & $6.36^{c}$ & $11.73^{a}$ \\
\hline$\alpha$-Phellandrene & $7.33^{b}$ & $12.85^{\mathrm{a}}$ & $6.42^{c}$ \\
\hline$\alpha$-Terpinene & $1.48^{c}$ & $1.63^{b}$ & $2.50^{\mathrm{a}}$ \\
\hline$\beta$-Phellandrene & $23.96^{\mathrm{b}}$ & $45.31^{\mathrm{a}}$ & $23.45^{c}$ \\
\hline$\beta$-Ocimene & $2.32^{\mathrm{c}}$ & $2.69^{b}$ & $5.11^{\mathrm{a}}$ \\
\hline$\Upsilon$-Terpinene & $2.26^{c}$ & $3.16^{b}$ & $5.42^{\mathrm{a}}$ \\
\hline$\beta$-Myrcene & 29.33 & - & - \\
\hline z-Ocimene & - & - & 0.99 \\
\hline $\begin{array}{l}\text { Terpinen-4-ol } \\
\text { Sesquiterpene } \\
\text { hydrocarbons }\end{array}$ & $9.71^{\mathrm{c}}$ & $12.89^{b}$ & $25.02^{\mathrm{b}}$ \\
\hline $\begin{array}{l}\beta \text {-Copaen } \\
\text { Monocyclic Diterpene } \\
\text { hydrocarbon }\end{array}$ & $2.29^{a}$ & $1.91^{b}$ & - \\
\hline m-Camphorene & 4.86 & - & - \\
\hline $\begin{array}{l}\text { p-Camphorene } \\
\text { Hydrocarbons and } \\
\text { their derivatives }\end{array}$ & 3.03 & - & - \\
\hline $\begin{array}{l}\text { 3,3-dimethyl-4-(methy } \\
\text { lamino)-2-Butanone }\end{array}$ & 1.52 & - & - \\
\hline Cyclodecane & - & 1.95 & - \\
\hline Decanal & - & 5.55 & - \\
\hline 1-octanol & - & 2.06 & - \\
\hline $\begin{array}{l}\text { Ethylamine,2-(adamatan } \\
\text {-1-yl)-1-methyl- }\end{array}$ & - & - & 1.39 \\
\hline $\begin{array}{l}\text { 1-(3,5-Dimethyl-1- } \\
\text { adamatanoyl) semicarbazide }\end{array}$ & - & - & 1.67 \\
\hline m-Methoxyamphetamine & - & - & 4.98 \\
\hline $\begin{array}{l}\text { Benzeneethanamine, } \\
\text { 4-methoxy- }\end{array}$ & - & - & 1.07 \\
\hline Phenylephrine & - & - & 2.58 \\
\hline Chloroacetamide & - & - & 2.49 \\
\hline Phosphinic amide & - & - & 2.82 \\
\hline
\end{tabular}

'-' stands for no compound present under the given place of Zanthoxylum chalybeum.In the designation ' $a$ ', 'b', ' $c$ ': the values with the same letter are not significantly different $(p<0.05)$

Table 5: Representative components of the essential oils for the three places

\begin{tabular}{lcccc}
\hline Compounds & $\begin{array}{c}\text { Awale } \\
(\%)\end{array}$ & $\begin{array}{c}\text { Awaday } \\
(\%)\end{array}$ & $\begin{array}{c}\text { Lange } \\
(\%)\end{array}$ & $\begin{array}{c}\text { Averge } \\
(\%)\end{array}$ \\
\hline $1 \quad \beta$-Myrcene & 29.33 & - & - & - \\
$2 \quad \beta$-Phellandrene & 23.96 & 45.31 & 23.45 & 30.91 \\
3 Terpinen-4-ol & 9.71 & 12.89 & 25.02 & 15.87 \\
5 Sabinene & 9.31 & 6.36 & 11.73 & 9.13 \\
$6 \alpha$-Phellandrene & 7.33 & 12.85 & 6.42 & 8.87 \\
Total & 50.31 & 77.41 & 66.62 & 64.78 \\
\hline
\end{tabular}

Though the three areas may have common components but their percentage composition varies with the sources of the essential oil, geographical 
coordination: Awale (latitude: $9.50^{\circ} \mathrm{N}$, longitude: $42.05^{\circ} \mathrm{E}$, and elevation: $1979 \mathrm{mtr}$ ); Awaday (latitude: $9.35^{\circ} \mathrm{N}$, longitude: $42.03^{\circ} \mathrm{E}$, and elevation: $2009 \mathrm{mtr}$ ), Lange (latitude: $9.44{ }^{\circ} \mathrm{N}$, longitude: $41.79^{\circ} \mathrm{E}$, and elevation: $2060 \mathrm{mtr}$ ). The chemical composition of essential oils is dependent upon the geographical locations for the reasons not known.

As compared to the other African Zanthoxylum chalybeum, the essential oils Zanthoxylum chalybeum of Eastern Ethiopia has a different chemical composition from that of the Eastern and Southern Africa confirming that chemical composition of the species varies as the species sources. The Eastern Ethiopia Zanthoxylum chalybeum leaves oil predominantly on average $71 \%$ is monoterpenes as compared to that of Uganda (27\%) and Zambia (25\%); $16 \%$ oxygenated monoterpenes as compare to that of Uganda (61\%) and Zambia (66\%); with the same total monoterpenoids amounting $88 \%$ as compare to Uganda (89\%) and Zambia (92\%). Zanthoxylum chalybeum leaves oil in Eastern Ethiopia is predominantly consists of monoterpenes while that of Uganda and Zambia predominantly consists of oxygenated monoterpenes. The common major component of Eastern Ethiopia Zanthoxylum chalybeum is $\beta$-phellandrene, $31 \%$ (average of the three areas) whereas the common major component from the East and Southern Africa (Zambia, Zimbabwe, and Uganda) is citral. Limonene is the major component in Eastern and Southern African countries. It is found that d-limonene induces neoplasms in the kidneys of male rats in association with hyaline droplet nephropathy. Since d-limonene is not in this research findings, the Zanthoxylum chalybeum leaves essential oils under the study is free of neoplasms mentioned earlier in the literature. The Eastern Ethiopia Zanthoxylum chalybeum shares a common terpinen-4-ol with the East and Southern Africa (Zambia, Zimbabwe, and Uganda). The Lange terpinen-4-ol (25.02\%) has more or less the same amount as that of Ugandan $(22.3 \%)$; the Awaleterpinen-4-ol $(9.71 \%)$ and the Awadayterpinen-4-ol (12.89\%) amount twice as that of Zambia (5.0\%) and Zimbabwe (5.3\%). Thus, the African Zanthoxylum chalybeum differ in composition as their source. The Eastern Ethiopia Zanthoxylum chalybeum shares myrcene, $\alpha$-pinene and sabinene with Zambia; $\alpha$-pinene, phellandrene $(\alpha-, \beta-)$ and decanal with that of Uganda. The Eastern Ethiopia
Zanthoxylum chalybeum has a different major and common chemical composition from that of the East and Southern Africa Zanthoxylum chalybeum but more or less it approaches to the chemical composition of the Uganda Zanthoxylum chalybeum, especially the Lange Zanthoxylum chalybeum, to some extent and to Zambia to a lesser extent may be attributed to the geological and climatic contrasts of the species sources as well as the differing age of plants.

\section{Antimicrobial Activity of the Essential oils}

The antimicrobial activity of the Zanthoxylum chalybeum leaf essential oils extracted by hydrodistillation collected from three different places of Eastern Ethiopia namely Awale, Awaday, and Lange were tested against two Gram-positive (Staphilococcus aureus and Streptococcus agalactiae) and two Gram-negative bacteria (Escherichia coli, Salmonella thyphimurium), chloroform (solvent as negative control) and chloramphenicol (as positive control), as shown in Table 6; as well as two fungi (Aspergillus niger, Fusarium oxysporium) and chloroform (solvent as negative control) and Tilt (Propiconazole, $\mathrm{C}_{15} \mathrm{H}_{17} \mathrm{Cl}_{2} \mathrm{~N}_{3} \mathrm{O}_{2}$ ), as positive control) as shown in Table 7. The disc diameter $(6 \mathrm{~mm})$ is excluded for all antimicrobial activities. Chloroform is used as a control to measure its inhibition zone as to subtract it from the total inhibition zone of the solution so as to get the net inhibition zone of the solute, essential oil. In all antimicrobial activities chloroform, the solvent showed no inhibition zone. All inhibition zones recorded were only the net inhibition zones for each oil solute of the plant.

According to Vaquero et al., ${ }^{16}$ no antimicrobial activity for inhibition zone $<1 \mathrm{~mm}$; antimicrobial activity for inhibition zone $\geq 1 \mathrm{~mm}$; weakly antimicrobial activity for inhibition zone $1 \mathrm{~mm}$; slight antimicrobial activity, for inhibition zone 2-3 mm; moderate antimicrobial activity, for inhibition zone 4-5 mm; high antimicrobial activity, for inhibition zone $6-9 \mathrm{~mm}$; and strong antimicrobial activity for inhibition zone $>9 \mathrm{~mm}$.

\section{Antibacterial Activities}

Referring to Table 6, all test essential oils of the different places and the reference drug chloramphenicol, showed different inhibition zone on each bacterial species. The negative control, 
chloroform (solvent) did not show inhibition zone on the respective bacteria species. All inhibition values of the test essential oils were entirely for the respected solutes, not the solution.

Table 6. Zone of bacterial growth inhibition 9 of the essential oils

\begin{tabular}{cccccc}
\hline Essential oil Samples & Dose $(\mu \mathrm{L})$ & \multicolumn{2}{c}{ Gram-positive bacteria } & \multicolumn{2}{c}{ Gram-negative bacteria } \\
& & S. aureus & Str.agalactiae & E.coli & S. thyphi \\
\hline Awale & 20 & $16.50 \pm 4.00$ & $17.17 \pm 2.89$ & $7.00 \pm 0.33 a$ & $19.17 \pm 1.44$ \\
Awaday & 20 & $17.83 \pm 2.11$ & $15.00 \pm 1.00$ & $5.35 \pm 0.87 \mathrm{a}$ & $21.67 \pm 0.89$ \\
Lange & 20 & $12.83 \pm 4.11$ & $14.35 \pm 1.11$ & $6.50 \pm 0.67 \mathrm{a}$ & $16.50 \pm 2.00$ \\
Chloroform & 20 & - & - & - & - \\
Chloramphenicol & 20 & 26.00 & 29.00 & 27.00 & 18.50 \\
$\%$ of Inhibition zone & & $60.46 \%$ & $53.48 \%$ & $23.26 \%$ a & $76.54 \%$ \\
\hline
\end{tabular}

'-' stands for no inhibition zone. Values are mean of three replications $9 \pm$ SD

Zanthoxylum chalybeum species essential oil is a broad spectrum essential oil in that both Gram-positive and Gram-negative bacteria are found to be strongly sensitive to it. The exception is E. coli (Gram-negative) bacterium, the least sensitivity of all the bacteria under investigations, showed high sensitive to all tested essential oils. The relatively less sensitivity of the $E$. coli bacterium is due to its impermeable thick murein layer which prevents the entry of inhibitors or else the inherited plasmids of its cell membrane to the essential oils ${ }^{17,18}$.

Referring to Table 7, S.thyphi(Gram-negative bacteria, $\mathrm{AIZbac}=19.11 \mathrm{~mm} \pm 1.74$ ) is the most sensitive of all bacteria followed by the two equally sensitive Gram-positive bacteria: S.agalactiae $(A I Z b a c=15.51 \mathrm{~mm} \pm 1.11)$ and S.aureus (AIZbac $=15.72 \mathrm{~mm} \pm 1.93$ ) to all three essential oil samples. The E.coli (Gram-negative with AIZbac $=6.28 \mathrm{~mm}$ \pm 0.62 ) bacterium showed the least sensitivity to all essential oil tests. All the values of the inhibition zone of the test essential oils have a value of almost the half value of the reference drug except S.typhi showed more or less the same inhibition zone values as the reference drug; and E.coli showed far less than the half inhibition zone values of the reference drug. E.coli is the least sensitive of all bacteria to the essential oils. Sensitivities of the essential oils to the S. thyphi (Gram-negative) and S.aureus (Gram-positive) bacteria decrease in the order: Awaday, Awale, Lange. Sensitivities of the essential oils to the S.agalactiae bacteria decrease in the order: Awale, Awaday, and Lange. Also, sensitivities of the essential oils to the E.coli bacteria decrease in the order: Awale, Lange, Awaday. Lange essential oils are the least sensitive of all the essential oils tested in all bacteria. The degree of antimicrobial activity of essential oil depends not only on the source of the essential oil but also on the type of bacteria strain under test.

Referring to Table 7, the essential oils of Awale (AIZEO $=14.96 \mathrm{~mm} \pm 3.98)$ and Awaday (AIZEO $=14.96 \mathrm{~mm} \pm 4.81$ ) have the same sensitivity to all bacteria whereas the essential oils of Lange (AIZEO $=12.55 \mathrm{~mm} \pm 3.02)$ is the least sensitive of all. Zanthoxylum chalybeum leaves essential oil has strong broad spectrum antibacterial properties with $\mathrm{AIZEO}=14.16 \mathrm{~mm} \pm 1.07$. A combination of antagonistic, synergistic and additive interactions plays a great role in the antimicrobial activities of the terpene components depending on concentrations and ratios of components. ${ }^{19,20}$

Table 7: The average inhibition zone (AIZ) for the samples

\begin{tabular}{|c|c|c|c|c|c|c|}
\hline \multirow{2}{*}{$\begin{array}{l}\text { Essential oils } \\
\text { of the places }\end{array}$} & \multirow[t]{2}{*}{ Dose $(\mu \mathrm{L})$} & \multicolumn{2}{|c|}{ Gram-positive bacteria } & \multicolumn{2}{|c|}{ Gram-negative bacteria } & \multirow{2}{*}{$\begin{array}{l}\text { Average } \\
\text { (AIZEO) }\end{array}$} \\
\hline & & S. aureus & Str.aga & E.coli & S. typhi & \\
\hline Awale & 20 & $16.50 \pm 4.00$ & $17.17 \pm 2.89$ & $7.00 \pm 0.33 a$ & $19.17 \pm 1.44$ & $14.96 \pm 3.98$ \\
\hline Awaday & 20 & $17.83 \pm 2.11$ & $15.00 \pm 1.00$ & $5.35 \pm 0.87 a$ & $21.67 \pm 0.89$ & $14.96 \pm 4.81$ \\
\hline Lange & 20 & $12.83 \pm 4.11$ & $14.35 \pm 1.11$ & $6.50 \pm 0.67 a$ & $16.50 \pm 2.00$ & $12.55 \pm 3.02^{b}$ \\
\hline Average(AIZbac) & & $15.72 \pm 1.93$ & $15.51 \pm 1.11$ & $6.28 \pm 0.62 a$ & $19.11 \pm 1.74$ & $14.16 \pm 1.07$ \\
\hline
\end{tabular}

' $a$ ' and ' $b$ ' indicate significant difference from the others. Mean inhibition zone \pm S.D

Chloramphenicol $(0.01 \mathrm{~g} / 4 \mathrm{~mL}=50 \mu \mathrm{g})$ is used as positive control ${ }^{21}$ 


\section{Antifungal Activities}

All the samples of the Zanthoxylum chalybeum leave extracted essential oils were found to be active to all the tested fungi species as shown in Table 8 below. The essential oils from Awale, Awaday and Lange showed anti-Asperigillus niger and Fusarium oxysporium fungal activity. Awale and Awaday showed high whereas Lange showed slight anti-Asperigillus nigerfungal activity. Awale essential oil showed slightly whereas Awaday and Lange essential oils are weakly anti-fusarium oxysporium fungal activity. ${ }^{16}$ Awale essential oil relatively better antifungal than Awaday and Lange essential oils. The Zanthoxylum chalybeum leaves essential oil in Eastern Ethiopia is found to have broad spectrum antifungal activities that vary as the source

Table 8: Zanthoxylum chalybeum leaves essential oils fungi growth zone inhibition

\begin{tabular}{lccc}
\hline Sample & Dose $(\mu \mathrm{L})$ & $\begin{array}{c}\text { Asperigillus } \\
\text { niger }\end{array}$ & $\begin{array}{c}\text { Fusarium } \\
\text { oxsporyum }\end{array}$ \\
\hline 1. Awaday & 20 & $6.67 \pm 0.52$ & $1.67 \pm 0.52^{\mathrm{a}}$ \\
2. Awale & 20 & $7.33 \pm 1.21$ & $3.00 \pm 0.63$ \\
3. Lange & 20 & $2.50 \pm 0.55 \mathrm{a}$ & $1.00 \pm 0.00^{\mathrm{a}}$ \\
4. Chloroform & 20 & - & - \\
5. Tilt $(100 \mu \mathrm{L} / 4 \mathrm{~mL})$ & 20 & $25.33 \pm 1.21$ & $26.67 \pm 0.82$ \\
\hline
\end{tabular}

The values represents mean of three replication $\pm \mathrm{SD}$; '-' stands for no inhibition for the chloroform solvent; [Tilt] $=100 \mu \mathrm{L} / 4 \mathrm{~mL}$; 'a' differs from the others

Table 9: AlZ with respect to essential oil and fungus

\begin{tabular}{lccc}
\hline Sample & Asperigillus niger & Fusarium oxsporyum & AIZEO \\
\hline 1. Awaday & $6.67 \pm 0.52$ & $1.67 \pm 0.52^{\mathrm{a}}$ & $4.17 \pm 2.09$ \\
2. Awale & $7.33 \pm 1.21$ & $3.00 \pm 0.63$ & $5.17 \pm 2.58$ \\
3. Lange & $2.50 \pm 0.55^{\mathrm{a}}$ & $1.00 \pm 0.00^{\mathrm{a}}$ & $1.75 \pm 0.75$ \\
AlZfu & $5.50 \pm 2.00$ & $1.89 \pm 0.74$ & $3.70 \pm 1.81$ \\
\hline
\end{tabular}

From Table 9, the most active oil against the tested fungi is Awale (AIZEO $=5.17 \mathrm{~mm} \pm$ 2.58, highly sensitive) followed by Awaday (AIZEO $=4.17 \mathrm{~mm} \pm 2.09$, moderately sensitive) and the least active oil is Lange (AIZEO $=1.75 \mathrm{~mm} \pm 0.75$, weakly sensitive). Asperigillus niger (AIZfu $=5.5 \mathrm{~mm}$ \pm 2.00 , highly sensitive) shows the most sensitive whereas Fusarium oxsporyum (AIZfu $=1.89 \mathrm{~mm} \pm$ 0.74 , weakly sensitive) is the least sensitive to the Z. chalybeum oils.

The myriad of essential oil bioactivity of the plant species is related to its intrinsic and extrinsic factors of the plant species. The intrinsic factors are relative percentage composition, lipophilic and hydrophilic properties, structural differences, the stereochemistry of the components and the possible synergistic interactions between them. The extrinsic factors refer to the plant's parts, stage of growth and its environment and the gram type test bacteria against which it is tested. Some compounds might enhance the growth of fungus while inhibiting various bacteria to differing extents. ${ }^{22,23,24}$

\section{CONCLUSION}

All essential oils of Zanthoxylum chalybeum leaves collected from Awale, Awaday and Lange contain similar major common components as $\alpha$-pinene, sabinene, $\alpha$-phellandrene, $\alpha$-terpinene, $\beta$-phellandrene, $\beta$-ocimene, $\Upsilon$-terpinene, and terpinen-4-ol terpenoids in various proportions of all, the most prevalent monoterpenes is $\beta$-phellandrene and the most prevalent oxygenated monoterpene is terpinen-4-ol in all essential oils of the places.

The essential oil components differ in their component composition as their sources. The most abundant monoterpene found only in Awale essential oil is $\beta$-myrcene. The minor monoterpene component found in the Lange area essential oil only is z-ocimene. The sesquiterpene hydrocarbons, $\beta$-copaen is detected in Awale and Awaday area only as a major component. Monocyclic diterpene hydrocarbon m-camphorene and $p$-camphorene are found as major components in the Awale area only. Hydrocarbons and their derivatives cyclodecane, decanal and 1-octanol were detected in Awaday essential oil; and 3, 3-dimethyl4-(methylamino)-2-Butanone was detected in Awale area essential oil only. Most nitrogenous compounds: ethylamine, 2-(adamatan-1-yl)-1-methyl-; 1-(3, 5-dimethyl-1-adamatanoyl) semicarbazide; m-methoxyamphetamine; phenylephrine; benzene ethaneamine, 4-methoxy-; chloroacetamide; phosphinic amide were detected only in Lange essential oil as major components. The three essential oils have the same similarities as they are from the same plant species and differ as to their sources in both the type and chemical composition of their constituents. All components of the essential oil make up for the uses of the physicochemical, antimicrobial and medicinal properties of the species. 
Zanthoxylum chalybeum leaves essential oil to possess antimicrobial activity properties ${ }^{25}$ and has been used for the treatment of various ailments in Ethiopia and abroad as mentioned in most literature the researcher has come across. The current research data obtained directly from the experimental value would confirm satisfactorily that the Ethiopian Zanthoxylum chalybeum leave essential oil is a broad-spectrum antimicrobial and encourage other researchers for further studies.

\section{ACKNOWLEDGEMENT}

Authors are grateful for the support received from The Department of Chemistry, Haramaya University, Ethiopia and Haramaya University Model School, Haramaya University, Ethiopia.

\section{Conflict of Interest}

We declare that there is no conflict of interest

\section{REFERENCES}

1. Lahlou, M., The Success of Natural Products in Drug Discovery. Pharmacology \& Pharmacy., 2013, 4(3), 17-27.

2. Getahun, A., Some common medicinal and poisonous plants used in ethiopian folk medicine Addis Abeba University Press: Addis Abeba., 1976, VG 07 \& HG 07.

3. WHO Legal Status of Traditional Medicine and Complementary/Alternative Medicine: A Worldwide Review., 2001, 200.

4. Belayneh, A.; Asfaw, Z.; Demissew, S.; Bussa, N. F., Medicinal plants potential and use by pastoral and agro-pastoral communities in Erer Valley of Babile Wereda, Eastern Ethiopia. Journal of Ethnobiology and Ethnomedicine., 2012, 8(1), 42.

5. WHO Traditional medicine., 2003, 4.

6. Nkunya M. H. H., H. W., D. H. Bray In Chemical Evaluation of Tanzanian medicinal plants for the active constituents as a basis for the medicinal usefulness of the plants, International Conference on Traditional Medicinal Plants, Arusha, Tanzania, 18-23 February, 1990; Dar Es Salaam University Press: Arusha, Tanzania., 1991, 11.

7. WHO WHO Traditional Medicine Strategy., 2013, 76, 2014-2023.

8. Regassa, R., Assessment of indigenous knowledge of medicinal plant practice and mode of service delivery in Hawassa city, southern Ethiopia. Journal of Medicinal Plants Research., 2013, 7(9).

9. Carson, C. F.; Hammer, K. A., Chemistry and Bioactivity of Essential Oils. In Lipids and Essential oils as Antimicrobial Agents., 2010, 203-238.

10. Van Strydonck, D. A. C.; Slot, D. E.; Van der Velden, U.; Van der Weijden, F., Effect of a chlorhexidine mouthrinse on plaque, gingival inflammation and staining in gingivitis patients: a systematic review. Journal of Clinical Periodontology., 2012, 39(11), 1042-1055.

11. Pongs, O., Chloramphenicol. Springer: Berlin, Heidelberg., 1979.

12. Bedoux, G.; Roig, B.; Thomas, O.; Dupont, V.; Le Bot, B., Occurrence and toxicity of antimicrobial triclosan and by-products in the environment. Environ Sci Pollut Res Int., 2012, 19(4), 1044-1065.

13. Meniso, B. G.; Boru, A. D.; Ganjinaboyina, n. B., Phytochemical investigation and evaluation of antimicrobial activities of stem bark of morella salicifolia. Bulletin of the chemical society of ethiopia., 2019, 33, 293.

14. Clevenger, J. F., Apparatus for the determination of volatile oil. Journal of the American Pharmaceutical Association., 1928, 17(4), 345-349.

15. Hutchinson, C. R., Biological methods for studying the biosynthesis of natural products. Natural Product Reports., 1986, 3.

16. Vaquero, M. J. R.; Alberto, M. R.; de Nadra, M. C. M., Antibacterial effect of phenolic compounds from different wines. Food Control., 2007, 18(2), 93-101.

17. A, A. I., Conjugal Transferability of Multiple Antibiotic Resistance in Three Genera of Enterobacteriaceae in Nigeria. Journal of Diarrhoeal Diseases Research., 1992, 10(2), 93-96.

18. Schelz, Z.; Molnar, J.; Hohmann, J., Antimicrobial and antiplasmid activities of essential oils. Fitoterapia., 2006, 77(4), 279-285.

19. Cox, S. D.; Mann, C. M.; Markham, J. L., Interactions between components of the essential oil of Melaleuca alternifolia. Journal of Applied Microbiology., 2001, 91(3), 492-497. 
20. Vuuren, S. F. v.; Viljoen, A. M., Antimicrobial activity of limonene enantiomers and 1,8cineole alone and in combination. Flavour and Fragrance Journal., 2007, 22(6), 540-544.

21. Mith, H.; Duré, R.; Delcenserie, V.; Zhiri, A.; Daube, G.; Clinquart, A., Antimicrobial activities of commercial essential oils and their components against food-borne pathogens and food spoilage bacteria. Food Science \& Nutrition., 2014, 2(4), 403-416.

22. Amaral, J. A.; Ekins, A.; Richards, S. R.; Knowles, R., Effect of Selected Monoterpenes on Methane Oxidation, Denitrification, and Aerobic Metabolism by Bacteria in Pure Culture. Applied and Environmental
Microbiology., 1998, 64(2), 520-525.

23. Cowan, M. M., Plant Products as Antimicrobial Agents. Clinical Microbiology Reviews., 1999, 12(4), 564-582.

24. Fatoki, O. A.; Onifade, D. A., Use of Plant Antimicrobials for Food Preservation. International Journal of Biological, Biomolecular, Agricultural, Food and Biotechnological Engineering., 2013, 7(12), 1110-1113.

25. Ocheng, F. Ugandan medicinal plants used traditionally for oral care: investigation of extracts for anti-bacterial, cytotoxic and antiinflammatory effects. Makrere University, Kampala, Uganda., 2015. 